\title{
Analisa Strategi Marketing Mix Menggunakan Konsep 4p (Price, Product, Place, Promotion) Pada Pt. Haluan Riau
}

\author{
Ahmad Mas'ari ${ }^{1}$, Muhammad Ihsan Hamdy ${ }^{2}$, Mila Dinda Safira ${ }^{3}$ \\ 1,2,3 Program Studi Teknik Industri, Fakultas Sains dan Teknologi, UIN Sultan Syarif Kasim Riau \\ Jl. HR. Soebrantas KM. 18 No.155 Simpang Baru, Pekanbaru, 28293 \\ Email: ahmad.mas’ari@uin-suska.ac.id,m.ihsanhamdy@uin-suska.ac.id,mila.dinda97@gmail.com
}

\begin{abstract}
ABSTRAK
Keberadaan media massa sudah menjadi bagian yang tidak terpisahkan dari masyarakat. Seiring dengan perkembangan industri media, berbagai strategi dilakukan oleh setiap perusahaan media agar dapat bertahan dan menjawab tantangan di tengah persaingan yang semakin tajam. Surat kabar Harian Umum Haluan Riau adalah sebuah surat kabar harian lokal yang diterbitkan oleh PT. Inti Kharisma Mandiri Riau. Demi tercapainya tujuan tersebut, perusahaan harus memiliki inisiatif strategi pemasaran agar mampu meningkatkan volume penjualan. Bauran pemasaran (Marketing Mix) merupakan salah satu faktor yang mempengaruhi volume penjualan dalam suatu perusahaan. Rangkaian marketing mix meliputi produk, harga, promosi, dan distribusi mempunyai pengaruh besar terhadap volume penjualan. Pengembangan produk dilakukan dengan cara membuat model dan desain lebih comfortable dan pemberian logo pada surat kabar Harian Umum Haluan Riau. Dalam menetapkan harga produk, PT. Haluan Riau mempertimbangkan berbagai faktor, seperti kondisi perekonomian, persaingan antar surat kabar, dan biaya yang dikeluarkan. PT. Haluan Riau melakukan pendistribusian secara langsung dan secara tidak langsung. PT. Haluan Riau juga melakukan strategi promosi dengan membuat periklanan, baik bersifat offline maupun online, personal selling, dan melakukan hubungan masyarakat dengan cara menjadi sponsor di berbagai lembaga pendidikan dan lembaga pemerintahan.
\end{abstract}

Kata Kunci: Bauran pemasaran, harga, produk, tempat, promotion.

\section{Pendahuluan}

Keberadaan media massa sudah menjadi bagian yang tidak terpisahkan dari masyarakat. Tidak lagi sebatas sebagai sumber jenis informasi, melainkan bisa berfungsi sebagai media pendidikan, hiburan, dan kontrol sosial. Bagi pengusaha, media massa berfungsi sebagai sumber pendapatan ekonomi. Fungsi media massa yang begitu strategis membuat prospek bisnis dalam industri media massa terbuka lebar.

Selain menjadi media utama informasi publik, media cetak juga menjadi sarana utama untuk mempertemukan para pembeli dan penjual. Walaupun media online semakin menjamur, namun eksistensi koran (offline) tidak bisa dipandang sebelah mata. Sebagai bagian dari produk pers, koran sudah menjadi bagian terpenting sebagai media informasi bagi publik dalam kehidupan berbangsa dan bernegara. Di Indonesia terdapat dua tipe koran dalam menghiasi bisnis media cetak yaitu: pertama, koran nasional. Jenis koran ini memiliki covered area atau jangkauan luas. Koran nasional dapat menjakup seluruh wilayah Repubik Indonesia dan biasanya berkedudukan di Ibu Kota negara, dan yang kedua adalah koran lokal. Ciri koran lokal adalah berada di daerah (provinsi/ kabupaten/ kota) dan memiliki covered area yang lebih sempit. Muatan atau content koran jenis ini lebih di dominasi oleh berita lokal (Munawara, 2017).

Pada umumnya, baik lokal maupun nasional, koran harian terbit setiap hari secara periodik, teratur, dan berkelanjutan. Oleh karena itu, koran bisa ditemui setiap saat sebagai bagian dari produk jurnalistik. Koran memuat empat unsur yaitu: berita (news), komentar (view), iklan (advertisement), dan publisistas (publicity). Keempat unsur tersebut dipadukan menjadi satu dan menjadi kekuatan dalam menjaga keberlanjutan penerbitan suatu Koran (Munawara, 2017).

Dewasa ini, tuntutan globalisasi makin mendesak badan usaha untuk selalu fleksibel mengikuti tuntutan perubahan, baik secara mikro maupun makro. Untuk menghadapi hal tersebut, perusahaan harus meningkatkan peran dalam proses 
pemasaran agar mampu meningkatkan penjualan. Bauran pemasaran (Marketing Mix) merupakan salah satu faktor yang mempengaruhi volume penjualan dalam suatu perusahaan. Rangkaian Marketing Mix meliputi produk, harga, promosi dan distribusi mempunyai pengaruh besar terhadap tindakan konsumen. Keempat unsur yang terdapat dalam Marketing Mix tersebut saling berhubungan dan masing-masing elemen di dalamnya saling mempengaruhi.

Surat kabar Harian Umum Haluan Riau sendiri adalah sebuah Surat Kabar harian lokal yang diterbitkan oleh PT. Inti Kharisma Mandiri Riau. Surat kabar ini hadir dengan serangkaian berita aktual yang tidak hanya meliputi berita dari kota Pekanbaru saja, namun Haluan Riau juga menyajikan berita-berita dari berbagai kabupaten dan kota di seantero provinsi Riau, nasional, bahkan internasional. Berita yang disajikan juga cukup variatif, hal ini terlihat dari ragam rubrikasi yang disajikan, mulai dari politik, ekonomi, sosial, olahraga, hiburan, dan lain sebagainya.

Bauran pemasaran atau Marketing Mix (4P) ini diaplikasikan di PT. Haluan Riau sebagai perusahaan Surat Kabar di area Kota Pekanbaru. PT. Haluan Riau ini memiliki rata-rata tingkat produksi 15.000 eksemplar per hari untuk permintaan di Kota Pekanbaru, Dumai, Siak, Bengkalis, Pelalawan, Indragiri hulu, Indragiri Hilir, Rokan Hulu, Rokan Hilir, Kampar, Kuansing dan Meranti (PT. Haluan Riau, 2019).

Di Kota Pekanbaru terdapat banyak jenis surat kabar. Oleh karena itu, PT. Haluan Riau harus dapat bertahan dalam persaingan industri ini. Berdasarkan permasalahan tersebut, akan dilakukan analisa strategi terhadap bauran pemasaran atau marketing mix (price, product, place, promotion) yang telah diaplikasikan oleh PT. Haluan Riau agar dapat bersaing di persaingan industri.

\section{Tinjauan Pustaka}

\section{Pers}

Menurut UU No. 40 Tahun 1999 merupakan landasan bagi pelaksanaan pers di Indonesia, Pasal 1 menyatakan bahwa: "Pers merupakan lembaga sosial dan wahana komunikasi massa yang melaksanakan kegiatan jurnalistik; meliputi, mencari, memperoleh, memiliki, menyimpan, mengolah, dan menyampaikan informasi, baik dalam bentuk tulisan, suara, gambar, suara dan gambar, serta data-data grafik maupun dalam bentuk lainnya dengan menggunakan saluran yang tersedia" (Suharyanto, 2016).

Secara umum, ada 4 (empat) fungsi yang dimainkan oleh pers, yaitu: fungsi informasi, fungsi hiburan, fungsi pendidikan, dan fungsi kontrol sosial (Jonriah 2008 dalam Suharyanto, 2016):

1. Fungsi informasi adalah fungsi pers yang paling standar. Munculnya jurnalistik adalah karena adanya informasi yang hendak disampaikan oleh pihak tertentu kepada khalayak masyarakat.

2. Fungsi hiburan juga cukup penting, karena manusia membutuhkan hiburan di sela-sela kehidupannya yang serba serius.

3. Fungsi pendidikan dari pers tidak kalah penting, karena pada dasarnya manusia membutuhkan berbagai tuntunan dan pelajaran dalam hidupnya. Pers diharapkan dapat memberikan kontribusi yang baik bagi pengembangan kepribadian manusia.

4. Fungsi kontrol sosial merupakan fungsi yang paling banyak disinggung dalam setiap perbincangan mengenai pers.

\section{Surat Kabar}

Surat kabar merupakan sinonim dari koran. Dalam Kamus Besar Bahasa Indonesia (KBBI) dinyatakan bahwa surat kabar merupakan lembaranlembaran kertas yang bertuliskan kabar atau berita yang terbagi-bagi atas kolom-kolom, terbit setiap hari atau secara periodik (Depdiknas Edisi Ketiga, 2003: 595 dalam Suharyanto, 2016).

Menurut Abidin, (2006: 32) dalam Suharyanto (2016) menyatakan bahwa: "Berita merupakan laporan tentang suatu peristiwa yang telah ataupun sedang terjadi, yang memperhatikan dan mengedepankan sisi kemanusiaan serta menarik perhatian sebagian besar pembaca/ pendengar/ penontonnya."

Surat kabar memiliki tiga fungsi utama dan fungsi sekunder. Fungsi utama media adalah (Suharyanto, 2016):

1. To Inform

Menginformasikan kepada pembaca secara objektif tentang apa yang terjadi dalam suatu komunitas, negara, dan dunia.

2. To Comment

Mengomentari berita yang disampaikan dan mengembangkannya ke dalam fokus berita.

3. To Provide

Menyediakan keperluan informasi bagi pembaca yang membutuhkan barang dan jasa melalui pemasangan iklan di media. 
Sedangkan fungsi sekunder media adalah (Suharyanto, 2016):

1. Untuk mengkampanyekan proyek-proyek yang bersifat kemasyarakatan yang diperlukan sekali untuk membantu kondisikondisi tertentu.

2. Memberikan hiburan kepada pembaca dengan sajian cerita komik, kartun dan cerita-cerita khusus.

3. Melayani pembaca sebagai konselor yang ramah, menjadi agen informasi dan memperjuangkan hak.

Kekhususan surat kabar dapat dilihat dari ciri-ciri sebagai berikut (Nasriah, 2012):

1. Publisitas, maksudnya surat kabar diperuntukkan umum karenanya berita, tajuk, artikel, dan lain-lain harus menyangkut kepentingan umum.

2. Universalitas, menunjukkan bahwa surat kabar harus memuat aneka berita mengenai kejadian-kejadian di seluruh dunia dan tentang segala aspek kehidupan manusia.

3. Aktualitas, maksudnya kecepatan penyampaian laporan mengenai kejadian di masyarakat kepada khalayak.

4. Periodisitas, berarti suatu penerbitan disebut surat kabar jika terbitnya secara periodik, dan teratur.

\section{Pemasaran}

Pemasaran dapat didefinisakan sebagai suatu proses sosial dan manajerial yang di dalamnya individu dan kelompok mendapatkan apa yang mereka butuhkan (needs) dan inginkan (wants) dengan menciptakan, menawarkan dan mempertukar produk yang bernilai dengan pihak lain (Da Aulia, 2013 dalam Daryanto, 2019).

Pemasaran merupakan suatu proses yang terdiri dari dua proses yaitu, secara sosial dan secara manajerial. Definisi sosial menunjukkan peran yang dimainkan oleh pemasaran di masyarakat. Seorang pemasar mengatakan bahwa peran pemasaran adalah menghasilkan standar yang lebih tinggi. Untuk definisi manajerial, pemasaran sering digambarkan sebagai seni menjual produk, tetapi orang heran ketika mendengar bahwa bagian yang paling penting dalam pemasaran bukanlah penjual.

Pemasaran adalah suatu proses sosial dan manajerial yang membuat individu dan kelompok memperoleh apa yang mereka butuhkan dan inginkan lewat penciptaan dan pertukaran timbal balik produk dan nilai dengan orang lain. (Kotler dan Amstrong, 2001 dalam Daryanto, 2019).

\section{Manajemen Pemasaran}

American Marketing Association (AMA) mendefinisikan manajemen pemasaran sebagai berikut: "Manajemen pemasaran sebagai seni dan ilmu memilih pasar sasaran dan mendapatkan, menjaga, serta menumbuhkan pelanggan dengan menciptakan, menyerahkan, dan mengomunikasikan nilai pelanggan yang unggul." Menurut definisi di ini, dapat dikatakan bahwa manajemen pemasaran merupakan suatu proses yang dimulai dari proses perencanaan, pengarahan, dan pengendalian produk atau jasa, penetapan harga, distribusi, dan promosinya dengan tujuan membantu organisasi dalam mencapai sasarannya (Kotler dan Keller, 2007 dalam Selang, 2013).

Pada umumnya ruang lingkup manajemen pemasaran meliputi, yaitu sebagai berikut (Assauri, 2010):

1. Falsafah manajemen pemasaran, yang mencakup konsep dan proses pemasaran serta tugas-tugas manajemen pemasaran.

2. Faktor lingkungan pemasaran merupakan faktor yang tidak dapat dikendalikan pimpinan perusahaan.

3. Analisis pasar, yang mencakup ciri-ciri dari masing-masing jenis pasar, analisis produk, analisis konsumen, analisis persaingan dan analisis kesempatan pasar.

4. Pemilihan sasaran (target) pasar, yang mencakup dimensi pasar konsumen, perilaku konsumen, segmentasi pasar dan kriteria yang digunakan, peramalan potensi sasaran pasar, dan penentuan wilayah pasar/penjualan.

5. Perencanaan pemasaran perusahaan, yang mencakup perencanaan strategi jangka panjang pemasaran perusahaan (marketing corporate planning), perencanaan operasional pemasaran perusahaan, penyusunan anggaran pemasaran dan proses penyususan pemasaran perusahaan.

\section{Bauran Pemasaran (Marketing Mix)}

Menurut (Kotler, 2002 dalam Daryanto, 2019), bauran pemasaran adalah sekumpulan alat pemasaran yang dapat digunakan oleh perusahaan untuk mencapai tujuan pemasarannya dalam pasar sasaran.

Pengertian bauran pemasaran adalah sebagai berikut: "Bauran pemasaran adalah perangkat alat pemasaran yang digunakan perusahaan untuk mengejar tujuan perusahaannya". Maka, dapat disimpulkan bahwa bauran pemasaran merupakan 
satu perangkat yang terdiri dari produk, harga, promosi, dan distribusi, yang di dalamnya akan menentukan tingkat keberhasilan pemasaran dan semua itu ditujukan untuk mendapatkan respon yang diinginkan dari pasar sasaran. (Kotler dan Keller, 2007 dalam Selang, 2013).

Sedangkan menurut (Saladin dan Oesman, 2002 dalam Daryanto, 2019), bauran pemasaran adalah serangkaian dari variabel pemasaran yang dapat dikuasai oleh perusahaan dan digunakan untuk mencapai tujuan dalam pasar sasaran. (Kotler dan Armstrong, 2001 dalam Daryanto, 2019) menyatakan bahwa bauran pemasaran sebagai perangkat alat pemasaran taktis dan terkontrol yang dipadukan oleh perusahaan untuk menghasilkan respon yang diinginkan pasar sasaran.

Marketing Mix merupakan variabel-variabel terkendali (controllable) yang dapat digunakan perusahaan untuk mempengaruhi tanggapan konsumen dari segmen pasar tertentu yang dituju perusahaan (Daryanto, 2019):

1. Produk

Menurut (Kotler, 2002 dalam Daryanto, 2019) produk adalah sesuatu yang ditawarkan ke dalam pasar untuk di perhatikan, dimilki, dipakai, atau dikonsumsi, sehingga dapat memuaskan keinginan atau kebutuhan. Intensitas kompetisi di pasar memaksa perusahaan untuk mengupayakan adaptasi produk yang tinggi guna meraih keunggulan yang kompetitif atas pesaing, karena adaptasi produk dapat memperluas basis pasar lokal dan ditingkatkan untuk preferensi lokal tertentu. Konsumen semakin banyak memiliki alternatif dan sangat hati-hati dalam menentukan keputusan untuk melakukan pembelian dengan mempertimbangkan faktor-faktor kebutuhan, keunggulan produk, pelayanan dan perbandingan harga sebelum memutuskan untuk membeli (Tjiptono, 2008 dalam Selang, 2013) [5].

2. Harga

Kotler dan Amstrong (2013 dalam Daryanto, 2019), harga adalah sejumlah uang yang dibayarkan untuk memperoleh barang atau jasa; sejumlah nilai yang konsumen tukarkan untuk menukarkannya dengan keuntungan untuk memperoleh barang atau jasa. Dari definisi di atas dapat diketahui bahwa harga yang dibayar oleh pembeli sudah termasuk layanan yang diberikan oleh penjual. Banyak perusahaan mengadakan pendekatan terhadap penentuan harga berdasarkan tujuan yang hendak dicapainya. Adapun tujuan tersebut dapat berupa meningkatkan penjualan, mempertahankan market share, mempertahankan stabilitas harga, mencapai laba maksimum dan sebagainya (Engel, J; Blackwell R, 2004 dalam Selang, 2013).

3. Harga

Menurut (Tjiptono, 2006 dalam Daryanto, 2019) menyatakan bahwa lokasi fasilitas jasa merupakan salah satu faktor krusial yang berpengaruh terhadap kesuksesan suatu jasa, karena lokasi erat kaitannya dengan pasar potensial penyedia jasa. Lokasi atau tempat seringkali ikut menentukan kesuksesan perusahaan, karena lokasi erat kaitannya dengan pasar potensial sebuah perusahaan.

4. Promosi

Menurut Tanton (dalam Suyanto, 2013 dalam Daryanto, 2019), promosi adalah unsur dalam bauran-bauran pemasaran perusahaan yang didayagunakan untuk memberitahu, membujuk, dan mengingatkan tentang produk pada suatu perusahaan. Promosi adalah suatu bentuk komunikasi pemasaran yang merupakan aktivitas pemasaran yang berusaha menyebarkan informasi, mempengaruhi atau membujuk dan meningkatkan sasaran pasar atas produknya agar bersedia menerima, membeli, dan loyal pada produk yang ditawarkan perusahaan yang bersangkutan. (Tjiptono 2007 dalam Selang, 2013).

\section{Metode Penelitian}

Penelitian ini bertujuan mengetahui marketing mix yang dilakukan PT. Haluan Riau

\section{Pengumpulan Data}

Tahap pertama, yaitu dengan mengumpulkan data dari perusahaan. Pengumpulan data yang dilakukan akan berpengaruh terhadap hasil penelitian secara keseluruhan.

a. Data Primer

Dalam penelitian ini, data primer diperoleh dengan metode observasi dan wawancara. Metode observasi ini dilakukan dengan cara mengamati secara langsung mengenai permasalahan di instansi dan mengumpulkan data yang dibutuhkan dalam melakukan penelitian dengan melakukan wawancara kepada beberapa pekerja. Proses memperoleh keterangan data untuk tujuan penelitian dengan cara tanya jawab dengan 
bertatap muka antara pewawancara dengan informan. Metode ini dilakukan dengan cara mewawancarai pekerja tentang strategi bauran pemasaran, seperti produk, harga, promosi dan tempat yang telah dilakukan pada PT. Haluan Riau.

b. Data Sekunder

Pada penelitian ini, data sekunder didapat melalui situs Haluan Riau di internet yang berkenaan dengan penelitian yang dilakukan. Data sekunder yang digunakan dalam penelitian ini adalah data yang sudah ada sejak instansi itu berdiri, adapun data yang diperoleh adalah sejarah singkat dan struktur instansi.

\section{Pengolahan Data}

Proses pengelolaan data dimulai dengan mengelompokkan data yang telah diperoleh dari penelitian lapangan, yaitu dari hasil observasi yang sudah dituliskan dalam bentuk catatan lapangan, hasil wawancara, serta dari arsip untuk diklarifikasikan dan dianalisis dengan menelaah seluruh data yang tersedia dari berbagai sumber. Proses analisis data yang dibutuhkan adalah analisis situasi diperlukan sebagai bagian dari strategi efektif untuk mencapai tujuan.

\section{Analisa}

Analisa data adalah suatu proses yang merinci untuk mengubah hasil dari pengolahan data menjadi sebuah informasi agar lebih mudah dimengerti dan berguna untuk solusi permasalahan yang terdapat dalam penelitian. Analisa data ini berisikan sebab akibat dari hasil pengolahan data yang telah dilakukan. Tujuan analisis data adalah untuk mendeskripsikan data yang dapat digunakan untuk mengambil kesimpulan. Pada penelitian ini, hasil pengolahan data dianalisa agar mendapatkan solusi dari strategi bauran pemasaran yang telah dilakukan di PT. Haluan Riau.

\section{Hasil dan Pembahasan}

\section{Produk (Product)}

Pada proses ini, PT. Haluan Riau melakukan strategi antara lain, yaitu:

a. Jenis Produk

Jenis surat kabar yang diterbitkan yaitu

Haluan Riau ini berisi tentang berbagai kabar terkini, berisi tentang seputar berita nasional dan berita internasional sedangkan bagian dua berisi tentang berita lokal.

\section{b. Pengembangan Produk}

Untuk menghadapi persaingan industri yang semakin ketat antar surat kabar, maka surat kabar Haluan Riau selalu berusaha mengembangkan produk melalu hal-hal sebagai berikut:

a. Model dan Desain Surat Kabar

Model dan desain surat kabar Haluan Riau mengacu pada model atau format penulisan surat kabar Jepang, di mana dalam penulisan model format ini dibuat lebih comfortable dengan ukuran halaman 540 x $425 \mathrm{~mm}$. Dengan model format tersebut diharapkan pembaca akan merasa lebih nyaman dalam membaca.

b. Pemberian Logo

Pemberian logo ini dilakukan agar konsumen dapat membedakan produk surat kabar Haluan Riau dengan surat kabar yang lain. Pemberian logo ini dimaksudkan agar masyarakat lebih familiar dengan logo surat kabar Haluan Riau.

c. Kualitas Produk

Persiapan yang dilakukan sebelum surat kabar Haluan Riau dipasarkan adalah melakukan quality control atau pengepakan. Hal tersebut dilakukan dengan maksud untuk memastikan bahwa produk yang dihasilkan merupakan produk yang benar-benar baik kualitasnya dan layak untuk dijual.

\section{Harga (Price)}

Haluan Riau menetapkan berbagai kebijakan, untuk mencapai tujuan yang diinginkan perusahaan. Kebijakan tersebut antara lain, yaitu:

a. Faktor yang mempengaruhi penetapan harga pada Harian Umum Haluan Riau

1. Kondisi Perekonomian

Kondisi perekonomian sangat mempengaruhi tingkat harga yang berlaku, yaitu adanya kenaikan harga bahan baku, apabila harga bahan baku naik, maka harga produksi menjadi naik. Maka dari itu, ketidakstabilan keadaan perekonomian sangat berpengaruh terhadap produk yang ditetapkan, sehingga Harian Umum Haluan Riau memberikan harga yang cukup terjangkau.

2. Persaingan

Haluan Riau selalu berusaha untuk meningkatkan kualitas berita, namun demikian harga jual ditekan serendah 
mungkin, setidaknya sama dengan pesaing. Hal ini dimaksudkan untuk merebut pangsa pasar yang lebih besar karena mampu menjangkau setiap lapisan masyarakat.

3. Biaya

Biaya merupakan salah satu faktor yang harus diperhitungkan dalam menetapkan harga, sebab sebuah perusahaan jika tidak menutup seluruh biaya-biaya yang telah dikeluarkan maka perusahaan tersebut akan merugi, demikian pula sebaliknya.

\section{b. Tujuan Penetapan Harga}

Tujuan penetapan harga yang dilakukan oleh Haluan Riau adalah untuk meningkatkan laba perusahaan. Pada penetapan harga produk sangat penting terhadap kebijakan strategi yang dilakukan karena harga dapat ikut menentukan posisi produk di pasar. Haluan Riau dalam hal ini mengambil kebijakan, yaitu harga surat kabar Harian Umum Haluan Riau sangat bersaing, yaitu sebesar Rp. 3000/eksemplar. Harga surat kabar dari sirkulasi ke agen sebesar Rp. 2.500/eksemplar, sementara dari agen ke pengecer sebesar Rp. 2.600/eksemplar.

\section{Distributor (Place)}

Dalam mendistribusikan surat kabar Harian Umum Haluan Riau menggunakan saluran distribusi langsung dan tidak langsung.

a. Saluran Distribusi Langsung

Pada saluran distribusi ini konsumen dapat langsung berlangganan melalui kantor perwakilan Haluan Riau Pekanbaru tanpa melalui perantara.

b. Saluran Distribusi Tidak Langsung

Terdapat tiga jenis saluran distribusi tidak langsung. Masing-masing saluran distribusi tersebut adalah:

1. Perwakilan - Pengecer - Konsumen

Pada saluran distribusi ini pengecer membeli secara langsung surat kabar Haluan Riau untuk dijual kepada konsumen akhir.

2. Perwakilan - Agen - Konsumen

Pada saluran distribusi ini perantara agen mencari pelanggan dan kemudian mendistribusikan surat kabar kepada pelanggan atau konsumen.

3. Perwakilan - Agen - Pengecer - Konsumen Pada saluran distribusi ini, agen mendistribusikan barangnya kepada sub agen atau pengecer yang kemudian menjualnya kepada konsumen.
Jadi, dengan keanekaragam saluran distribusi yang dimilikioleh Haluan Riau diharapkan dapat memudahkan konsumen dalam memperoleh Surat Kabar Harian Umum Haluan Riau.

\section{Promosi (Promotion)}

Kegiatan promosi merupakan salah satu kegiatan penting dalam proses pemasaran. Untuk itu Haluan Riau selalu aktif dalam berbagai kegiatan promosi. Bentuk-bentuk kegiatan promosi yang dilakukan oleh Haluan Riau antara lain, yaitu:

a. Periklanan

Salah satu keunggulan periklanan yaitu mempunyai jangkauan konsumen yang luas. Bentuk periklanan yang dilakukan oleh Haluan Riau antara lain:

1. Periklanan dilakukan dengan pemasangan baliho, pamflet, serta spanduk tempattempat umum. Perikalan ini bertujuan untuk lebih mengenalkan Haluan Riau kepada masyarakat umum. Sehingga masyarakat menjadi kenal, kemudian tertarik dan membeli koran Haluan Riau.

2. Periklanan juga dilakukan melalui website dengan alamat www.harianhaluan.com.

b. Personal Selling

Kegiatan promosi juga dilakukan melalui personal selling, yaitu dengan door to door oleh para SPG misalnya penawaran berlangganan harian Haluan Riau, penawaran paket iklan dengan pemberian brosur dan sebagainya.

c. Hubungan Masyarakat

Promosi yang dilakukan melalui hubungan masyarakat dilakukan dengan cara menjalin kerjasama dengan berbagai lembaga pendidikan seperti Universitas Riau, Universitas Islam Negeri Sultan Syarif Kasim, dan lain-lain. Kegiatan hubungan masyarakat tersebut antara lain menjadi sponsor dalam kegiatan seminar, lokakarya, dan lain-lain.

Sedangkan hubungan masyarakat melalui lembaga pemerintahan dilakukan dengan cara menjadi sponsor pada berbagai acara festival Pekanbaru, seperti: Pekanbaru Fun City Rally, Suku Seni Riau, Unique Car Festival, dan lain sebagainya.

\section{Pengaruh Marketing Mix terhadap Volume Penjualan}

Penerapan Marketing Mix yang dilakukan oleh Haluan Riau meliputi produk, harga, distribusi, dan promosi tentunya mempunyai pengaruh terhadap penjualan produk. Untuk mengetahui sejauh mana pengaruh marketing mix terhadap 
volume penjualan pada PT. Haluan Riau dapat dilihat dalam tabel volume penjualan berikut:

Tabel 4.1 Data Penjualan Koran Bulan Januari Oktober 2019:

\begin{tabular}{|c|c|c|}
\hline No. & Bulan & $\begin{array}{c}\text { Rata- Rata } \\
\text { Penjualan }\end{array}$ \\
\hline 1. & Januari & 334.000 \\
\hline 2. & Februari & 345.000 \\
\hline 3. & Maret & 282.000 \\
\hline 4. & April & 312.000 \\
\hline 5. & Mei & 330.000 \\
\hline 6. & Juni & 315.000 \\
\hline 7. & Juli & 321.000 \\
\hline 8. & Agustus & 331.000 \\
\hline 9. & September & 353.000 \\
\hline
\end{tabular}

(Sumber: PT. Haluan Riau, 2019).

Dari tabel tersebut dapat dilihat volume penjualan pada surat kabar Haluan Riau bulan Januari - September Tahun 2019 secara keseluruhan cenderung mengalami peningkatan. Peningkatan penjualan secara signifikan dirasakan pada 3 bulan terakhir yaitu pada bulan Juli - September. Penurunan volume penjualan terjadi pada bulan Maret, yaitu sebesar 282.000 eksemplar dan pada bulan Juni sebesar 315.000 eksemplar. Peningkatan volume terbesar terjadi pada bulan September, yaitu sebesar 353.000 eksemplar. Hal ini menunjukkan bahwa penerapan Marketing Mix pada PT. Haluan Riau secara keseluruhan memberikan dampak positif terhadap peningkatan volume penjualan perusahaan.

Berdasarkan adanya peningkatan volume penjualan dari bulan ke bulan pada PT. Haluan Riau menunjukkan bahwa perusahaan dapat bertahan di persaingan industri media cetak yang semakin ketat dan menunjukkan bahwa perusahaan pada tahap kedewasaan yang meningkat, hal ini ditunjukkan dengan adanya volume penjualan total yang semakin meningkat.

\section{Kesimpulan}

Berikut ini merupakan kesimpulan yang dapat diambil pada penelitian ini adalah sebagai berikut:

a. Strategi marketing mix terhadap product yang dilakukan oleh PT. Haluan Riau, yaitu:

1. Jenis produk berupa surat kabar Harian Umum Haluan Riau.

2. Pengembangan produk dengan mengembangkan model dan desain surat kabar serta pemberian logo yang dapat membedakan produk surat kabar Harian Umum Haluan Riau dengan surat kabar lainnya.

b. Strategi Marketing Mix terhadap price yang dilakukan oleh PT. Haluan Riau, yaitu:

1. Faktor yang mempengaruhi penetapan harga pada Harian Umum Haluan Riau adalah: kondisi perekonomian, persaingan, dan biaya.

2. Tujuan Penetapan Harga.

c. Strategi Marketing Mix terhadap place yang dilakukan oleh PT. Haluan Riau, yaitu:

1. Saluran Distribusi langsung (Kantor Perwakilan - Konsumen).

2. Saluran Distribusi Tidak Langsung

a. Perwakilan - Pengecer - Konsumen

b. Perwakilan - Agen - Konsumen

c. Perwakilan - Agen - Pengecer Konsumen.

d. Strategi Marketing Mix terhadap promotion yang dilakukan oleh PT. Haluan Riau, yaitu:

1. Periklanan

a. Pemasangan baliho, pamflet, dan spanduk di tempat-tempat umum.

b. Periklanan melalui website dengan alamat www.harianhaluan.com.

2. Personal Selling

3. Hubungan Masyarakat
a. Kerjasama dengan lembaga pendidikan
b. Kerjasama dengan lembaga pemerintahan.

e. Dalam persaingan industri antar media cetak, PT. Haluan Riau dapat bertahan dengan menerapkan strategi Marketing Mix. Penerapan Marketing Mix pada PT. Haluan Riau memberikan dapmpak positif terhadap peningkatan volume penjulalan surat kabar Harian Umum Haluan Riau.

\section{Daftar Pustaka}

[1] Assauri, Sofjan. 2010. Manajemen Pemasaran. Jakarta: PT. Raja Grafindo Persada.

[2] Daryanto, L. H., dan Hasiholan, L. B. The Influence Of Marketing Mix On The Decision To Purchase Martabak "Setiabudi"Pak Man Semarang. Journal of Management, Vol. 5, No. 5, 2019.

[3] Munawara, Munawara. Startegi Marketing Koran Harian Amanah dalam Menghadapi 
Persaingan Industri Media Cetak. Diss. Universitas Islam Negeri Alauddin Makassar, 2017.

[4] Nasriah, S. N. Surat Kabar Sebagai Media Dakwah. Jurnal Dakwah Tabligh Vol. 13, No. 2, 2012.

[5] Selang, C. A. Bauran pemasaran (marketing mix) pengaruhnya terhadap loyalitas konsumen pada fresh mart Bahu Mall Manado. Jurnal EMBA:Jurnal Riset Ekonomi, Manajemen, Bisnis dan Akuntansi Vol. 1, No. 3, 2013.

[6] Suharyanto, A. Surat Kabar Sebagai Salah Satu Media Penyampaian Informasi

Politik pada Partisipasi Politik Masyarakat. Jurnal Administrasi Publik:Public Administration Journal Vol. 6, No. 2, 2016. 